\title{
うず巻ばねの数值解析
}

\section{On the Numerical Analysis of Spiral Springs}

\begin{abstract}
下関 正義 ${ }^{* *} \cdot$ 藤沼 平一**・折原 進 ${ }^{* *} \cdot$ 篠原 宣昭***
\section{Masayoshi SHIMOSEKI • Heiichi FUJINUMA · Susumu ORIHARA Nobuaki SHINOHARA}

わが国には，うず巻ばねに関する先駆的な研究報告 1)がある. 近年の海外の報告を見ても， 1)を越之るものは見当らない.たとえば，文献 2)の考之方は文献 1)と全く同様であるし，また 文献 3)などはむしろ根拠の薄い仮定に立脚している，また，うず巻ばねの計算式は積分方程式 として定式化されてしまうために，手計算では実際の解析が困難であった。そこで，本報では 文献 1），2）の考之方をさらに発展させ，数值的解法にまで拡張したものである．そうすること によって, 焼鈍部での材料定数の変化を考慮したり，各部の残留応力を算出したりする，より キメの細かい検討が可能になることを示した.
\end{abstract}

We can find the leading paper on spiral springs which had been published in 1952 in Japan. Among foreign reports published in recent years, we can not find papers that surpass the reference 1). For example, the paper 2) based on the same idea as the paper 1) and the paper 3 ) is rather based on weak grounded suppositions. And, because the equation of spiral springs is expressed into integral equation, it is difficult to analyze practically by manual calculation. Therefore, in this report, we try to analyze numerically such integral equation based on the idea of reference 1) and 2). Applying this method, it becomes possible to consider the distribution of material constants through the annealed transition zone Furthermore, we can get the residual stress distribution along the strip.

\section{1. まえがき}

文献 1)は，うず巻ばねに関する先駆的な研究報告で ある。その特徴は，うず巻ばねを成形加工したときの 自由状態の形状を弾塑性解析に基づいて解析的に導出 しているところにある.こうしたことが，最近の海外 の報告に比べてみても，内容的に優れている理由であ る. たとえば, 文献 2)の考え方は文献 1) と全く同様で あるし，また文献 3）では，アプリオリに自由状態の形 状を単純な関数で近似するという根拠の乏しい仮定に 立脚している。文献 1)，2）のように，ばねの自由状態 形状を解析的に求めていれば，適用範囲の拡張が容易 であり，本報はそれらの考え方をさらに発展させたも のとして位置づけられよう。

本報では，積分方程式として定式化されてしまうう ず巻ばねの計算式を, 計算機による数值的解法によっ て処理を行なっている，そうすることで，本報は，

一自由状態の形状を正確につかむために，焼鈍部で

原稿受付日 昭和 62 年 9 月 30 日

* ばね技術研究会 昭和 61 年度秋季講演会にて発表

** 三菱製鋼株式会社 (Mitsubishi Steel Mfg. Co.,Ltd.)

*** プレシジョンスプリング株式会社(Precision Spring Co.,Ltd.)
の材料定数の分布を考慮する.

- 発生応力を正確に求めるために, 各部分での残留 応力を算出する。

などの，より現実に則した解析が可能であることを示 している.さらに, 本報は, 解析的に得られている自 由状態形状を求めるのに用いられる材料定数を，いく つかの簡単な実験的方法によって推定が可能であるこ とを明らかにしている。

なお，本報での数值解析は手軽に使えるパーソナル 計算機を利用し, BASICのグラフィック機能を活用し ている.

\section{2. 基本的な考元方}

うず巻ばねの数值解析の目的は, ばねのトルクと巻 数の関係つまりトルク特性並びに鋼帯表面の応力分布 とを予測する特性計算と, また逆に要求仕様に合致し たばね形状，加工条件などを決定する設計計算を可能 にすることである.また, 数值解析のポイントは, ば ねの自由状態での形状と, 初期残留応力とを解析的に 得ることである。ここでは, 数值解析に至るまでの基 本的な概念を示す.

また，式の具体的内容については，6．補遺の章を 参照されたい. 


\section{1 主な記号}

数値解析に必要な各量を, それらの性質から 4 つの グループに分け，それぞれ表1の記号を付ける。また， 数值解析の目的と各量との関係を概念的に図示すれば, 図1のようになる。

表 1 主な記号

\begin{tabular}{c|c|c}
\hline \multirow{2}{*}{ ばね諸元 } & $h$ & 板厚 \\
\cline { 2 - 3 } & $I$ & 断面 2 次モーメント \\
\cline { 2 - 3 } & $l$ & 展開長 \\
\hline \multirow{2}{*}{ 使用空間 } & $d_{c}$ & 香箱径 \\
\cline { 2 - 3 } & $d_{s}$ & 軸径 \\
\hline \multirow{2}{*}{ 加工条件 } & $d_{1}$ & 1 次巻径 \\
\cline { 2 - 3 } & $d_{2}$ & 2 次巻軸径 \\
\hline \multirow{4}{*}{ 材料定数 } & $E_{1}$ & 弾性係数 \\
\cline { 2 - 3 } & $E_{2}$ & 塑性係数 \\
\cline { 2 - 3 } & $\sigma_{y}$ & 降伏応力 \\
\hline
\end{tabular}

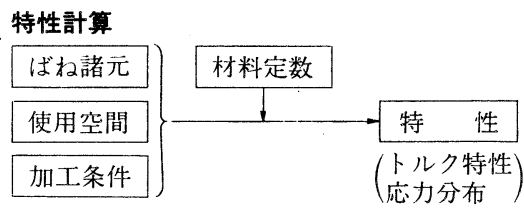

\section{設計計箅}

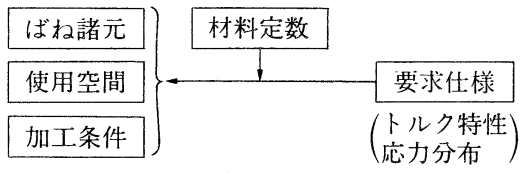

図 1．特性計算と設計計算

\section{2 ばねの動き得る範囲}

自由状態のばねを香箱内に収め，鋼带の全てが香箱 面内にはり付いた状態での鋼帯に沿った曲率分布を $x_{c}$ とし，さらにばねを完全に卷き締めて全てが軸に巻き 付いた状態での曲率分布を $x_{s}$ として,これらを図 2 の 曲率線図上に描いてみる。ただし，曲率線図は縦軸が 曲率 $x$ を表わし，横軸は軸側から鋼帯に沿って·とった 長さ $s$ を表わしている. $x_{c}$ は図 2 の $[C D], x_{s}$ は $[A B]$

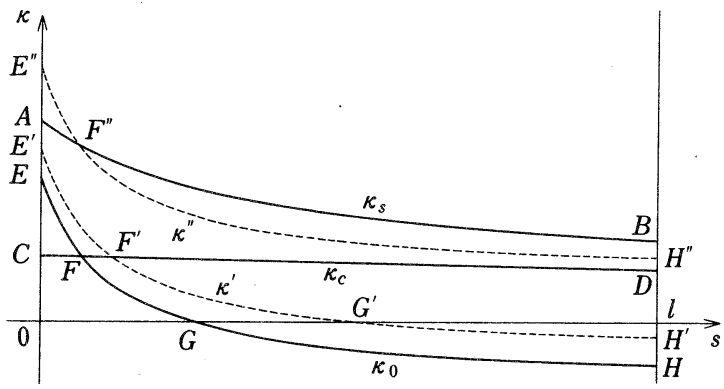

図 2。曲率線困（概念図）
のようなピッチを $h$ とするアルキメデス曲線となる. 当然これらの曲率は $h, l, d_{c}, d_{s}$ の幾何学的形状に よって純粋に与えられ， $x_{c} ， x_{s}$ はこれらの関数として 表わされるものである。すなわち，

$$
\begin{aligned}
& x_{c}=x_{c}\left(s ; d_{c}, h, l\right) \\
& x_{s}=x_{s}\left(s ; d_{s}, h\right)
\end{aligned}
$$

使用状態でのばねの曲率分布 $x$ を考之てみると，当然 のことながら，必ず

$$
x_{c} \leqq x \leqq x_{s}
$$

の範囲内にあることになる.

2.3 自由状態の曲率分布

$S$ 字形うず巻ばねは 2 度成形加工される。1 1 次巻成 形は強制加工であるため, そのときの曲率分布 $\chi_{1}$ には 任意性がある.これに対して，2 次巻成形は軸径 $d_{2}$ の 2 次巻軸に密着巻きにして加工される，このため， 2 次巻成形時の曲率分布 $\chi_{2}$ は $\chi_{c}, x_{s}$ と同様にピッチを $h$ とするアルキメデス曲線となる。すなわち $x_{1}, x_{2}$ は次 式の形で与えられる。

$$
\begin{aligned}
& x_{1}=x_{1}(s) \\
& x_{2}=x_{2}\left(s ; d_{2}, h\right)
\end{aligned}
$$

$S$ 字形でないうず巻ばね，つまり鋼帯を成形軸に巻 きつけてセッチングされた単純うず巻形ばねについて は，(4)，(5)式において $x_{1}=0$ とし，さらにセッチング 時の曲率分布を $x_{2}$ (成形軸径 $d_{2}$ ) と考えれば良く, $S$ 字 形のうず巻ばねと全く同様に扱うことができる。した がって以下の考え方で，S字形の場合と単純うず卷形 の場合との区別は必要ない。

さて，成形加工後におけるばねの自由状態の曲率分 布 $\chi_{0}$ は，(4)，(5) 式の 2 つの加工条件と材料定数とに 依存し，それらの関数として

$$
\chi_{0}=\chi_{0}\left(s ; \chi_{1}, \chi_{2}, h, E_{1}, E_{2}, \sigma_{y}\right)
$$

のように与えることができる. (6)式にパラメータとし て入ってくる材料定数 $E_{1}, E_{2}, \sigma_{y}$ の物理的な意味は図 3 に示すように材料特性を線形ひずみ硬化型と近似し た場合のものである。もちろん，塑性域における応力 ひずみ関係をさらに多くの直線近似のつながりによる 定式化も可能であるが，式の煩雑さを避けるため，並 びに材料定数の推定のしやすさなどを考えて，図 3 の ような材料特性の近似を採用する。

\section{4 鋼带表面の残留応力}

1 次巻成形後のテンパー処理によって，鋼带内部の Uずみは除去されるため, ばねに残留する応力は 2 次 巻成形加工によるものである，いま，鋼帯表面の残留 応力を $\sigma_{0}$ とするならば, (6) 式と同様に $2 \supset$ 加工条件 と材料定数の関数として,

$$
\sigma_{0}=\sigma_{0}\left(s ; \chi_{1}, \chi_{2}, h, E_{1}, E_{2}, \sigma_{y}\right)
$$

と与えられる。

\section{5 ばねの挙動}

(6) 式の $x_{0}$ を図 2 に描いてみると, $(E F G H)$ のよう 


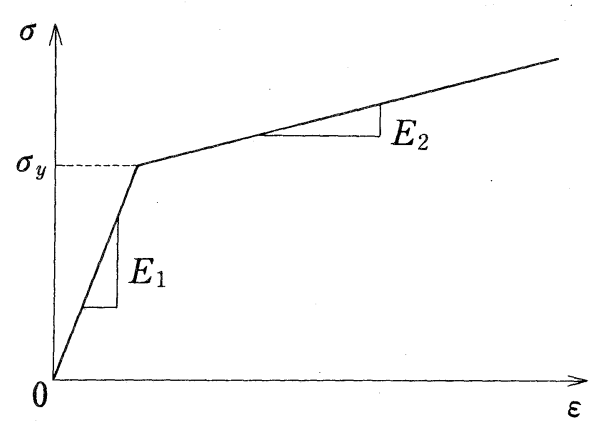

図 3 . 材料特性

になる.ここで,この場合のように，

$$
x_{0}>0[E G], \quad x_{0}<0[G H]
$$

となっているため, $S$ 字形という呼び名が付いている. ところで,

$x_{0}[F H]<x_{c}[F D]$

であるために，ばねを香箱内に収めたとき，この区間 は強制的に $(F D)$ 曲線に拘束されるわけで, 全体として, ばねを香箱内に収めたときには，

$$
x_{0}[E F], x_{c}[F D]
$$

という曲率分布になる。

さて，摩擦を無視し，巻締め，あるいは巻戻し時に 巻数が充分多ければ内，外端での反力は無視できるた め，ばねの有効部に作用する曲げモーメントは一様と みなせ,これが軸に生じるトルクに等しいと仮定する。 つまク，ばねにトルクが負荷されたときに，鋼帯には 一様な曲げモーメントが作用するものと仮定すれば, 各部分における曲率変化 $\Delta x$ は，

$$
\Delta x=T /\left(E_{1} I\right)
$$

となるので，このときの仮想的な曲率分布 $x^{\prime}$ は

$$
x^{\prime}(s)=x_{0}(s)+\Delta x
$$

となるはずである。これを図示すれば, 図 2 の $\left(E^{\prime} F^{\prime} H^{\prime}\right)$ のようになる。もちろん，

$$
\chi^{\prime}\left[F^{\prime} H^{\prime}\right]<x_{c}\left[F^{\prime} D\right]
$$

であるから，実際にはトルクTの負荷時には，

$$
\chi^{\prime}\left[E^{\prime} F^{\prime}\right], \varkappa_{c}\left[F^{\prime} D\right]
$$

という曲率分布となる。

一方，このときのばねの巻数 $N$ は $s=0$ と $s=l$ との 相対的な角度変化を $\varphi$ として計算され,

$$
\begin{aligned}
N & =\varphi / 2 \pi=\int_{E F D}^{E^{\prime} F^{\prime} D} \Delta x \cdot d s / 2 \pi \\
& =\text { 面積 }\left(E F F^{\prime} E^{\prime} E\right) / 2 \pi
\end{aligned}
$$

で与えられる。

さらに, トルクが増加して，ばねの仮想的な曲率分 布が図 2 の $\left(E^{\prime \prime} F^{\prime \prime} H^{\prime \prime}\right)$ のようになったとすれば，この ときの実際のばねは，

$$
\varkappa_{s}\left[A F^{\prime \prime}\right], \varkappa^{\prime \prime}\left[F^{\prime \prime} H^{\prime \prime}\right]
$$

という曲率分布となるだけで，考え方は全く同じであ

る.このときのばねの巻数 $N$ は,

$$
N=\text { 面積 }\left(A E F D H^{\prime \prime} F^{\prime \prime} A\right) / 2 \pi
$$

で与えられる。

\section{3. 材料定数の推定}

解析に必要な各量のうち，ばね諸元，使用空間，加 工条件は特性計算の場合あらかじめわかっているか, あるいは設計計算によって決定されるものである。特 性計算, 設計計算いずれの場合にしろ解析を正確に行 なうためには，ばねの材料特性を図 3 のように近似し たときの材料定数 $E_{1}, E_{2}, \sigma_{y}$ を正確にとらえておく必 要がある。

ここでは, うず巻ばね材料として良く用いられる SUS 301-CSP EH 材を対象とし, 次に示す実験的手段によ る，材料定数の推定方法について述べる.

*材料の引張試験 $\cdots \cdots \cdots \cdots \cdot E_{1}$ の推定

* 自由状態の形状測定 $\cdots \cdots E_{2}, \sigma_{y}$ の推定

* 焼鈍部硬さ分布測定……焼鈍部 $E_{2}, \sigma_{y}$ の推定

3.1 弾性係数 $E_{1}$ の推定

ばねの 2 次巻成形及び使用状態は，いずれもテンパ 一処理後であるため, このときの $E_{1}$ が必要となる。そ こで，テンパー処理後の鋼帯から図 4 に示す形状の試

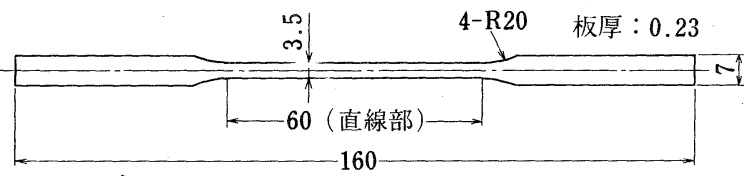

図 4. 引張試験片形状

験片を取り出し，引張試験の供試材とする。このよう に引張試験により $E_{1}$ の推定を行なう。なお, 試験片中 央にはり付けられた 1 方向UずみゲージによってUず みが測定される。

\section{2 塑性係数 $E_{2}$, 降伏応力 $\sigma_{y}$ の推定}

$E_{2}, \sigma_{y}$ の推定は実際のばねの自由状態形状から行な うのが自然である．先ず，ばねの自由状態の形状を鋼 带に沿って任意の位置を $x, y$ 平面座標として測定す る。この測定は次に述べる曲率計算が充分な精度で行 なえる程度の数が必要である，実際の自由状態の形状 測定点の位置を図 5 a の○印で示す。この自由状態の 形状測定の後, 連続した测定点 3 点を通る円弧の半径 によりその位置での曲率を計算し，对応する円弧の長 さの総和を以って鋼帯に沿った長さ $s$ を算出する。こ の測定曲率を図 5 bに示す曲率線図上にプロットし, さらに $(6)$ 式の $x_{0}$ 中のパラメー夕 $E_{2}, \sigma_{y}$ を適宜変化さ せてプロットされた測定曲率に $\chi_{0}$ が添うような $E_{2}, \sigma_{y}$ 


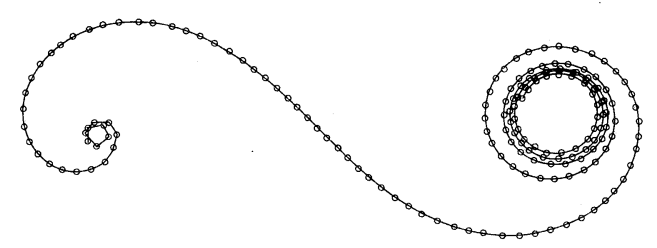

図 5，a，自由状態のうず巻ばね形状測定点

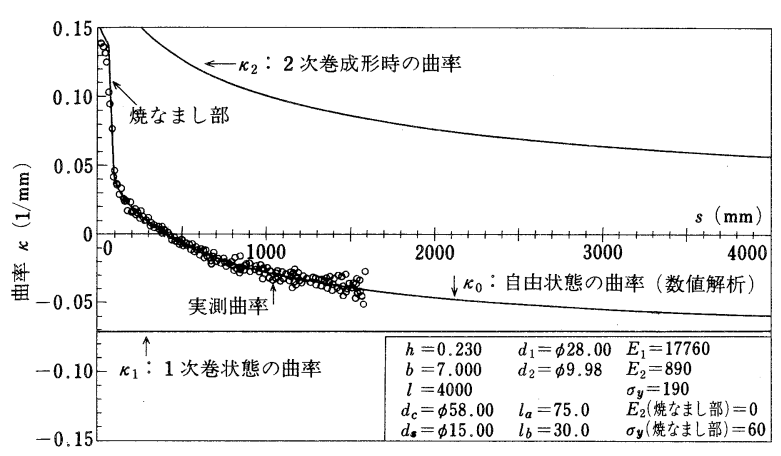

図 5，b．測定曲線

の值をみつけ出す.ここで(6)式中のパラメータ $x_{1}, x_{2}$, $h$ は既知であり，また $E_{1}$ は前節によって得られている 值である。

実際の $E_{2}, \sigma_{y}$ の推定では, 加工条件 $d_{2}$ の異なる 3 種類のばねの測定曲率に共通に満足する $E_{2}, \sigma_{y}$ の值を 探し出し, これらを以ってこの材料の $E_{2}, \sigma_{y}$ としてい る.

\section{3 焼鈍部の材料定数 $E_{2}, \sigma_{y}$ の推定}

多くのうず卷ばねでは, その端部にフックの曲げ追 加工のための焼鈍部分を持っている.より現実に則し た解析を行なうためには，焼鈍部分の材料定数の変化 も考慮する必要がある.

SAE J 417 bによれば, ビッカース硬さと引張強さ との関係が明らかである. したがって, いま引張強さ と降伏応力とが比例するものと仮定するならば，焼鈍 部の硬さの測定によりその部分での降伏応力を一義的 に推定できる、また，焼鈍部とばね有効部との中間に ある移行部分での硬さ分布は何本かの直線で線形補間 し，この補間值をもとにして鋼帯に沿った各位置での $\sigma_{y}$ を推定する.

さらに，焼鈍部においての材料特性は弾完全塑性体 と仮定し，また $E_{2}$ についても硬さに関して $\sigma_{y}$ と同様 な仮定を設定すれば, 移行部分各位置での $E_{2}$ の值を線 形補間によって算出することができる。

硬さ分布測定は, 比較的容易に行なうことが可能で あるので，焼鈍部の材料特性の推定には特に有効であ る. 図 5 bの曲率線図においては, 以上のようにして 推定された焼鈍部, 移行部の各位置の $E_{2}, \sigma_{y}$ の分布よ
り計算される $\chi_{0}$ を示しており，有効部のみならず，焼 鈍部，移行部においても実測された測定曲率によく一 致している.

\section{4 材料定数の決定}

材料特性が図 3 の線形ひずみ硬化型であると近似し た場合，前節までの実験的方法により，対象としてい る材料の材料定数は表 2 のよjに決めることができる. また，他の材料についても，同様の実験によって比較 的容易にその材料定数を決めることが可能である．た だし，同一材料であってもテンパー処理条件や焼鈍処 理条件が異なれば，そのつど材料定数を決め直さなけ ればならない。

\section{4. 数值解析}

ここでは計算機を利用した数值解析例を示す．解析 に用いたうず巻ばねの材料及び材料定数は表 2 で，ま たばねの諸元及び要求仕様は表 3 に示す通りである。

\section{表 2 材料定数}

\begin{tabular}{c|lcc}
\hline \multicolumn{1}{c|}{ 材 } & \multicolumn{3}{|c}{ SUS 301-CSP EH } \\
\hline \multirow{3}{*}{ 材料定数 } & $E_{1}$ & 17760 & $\mathrm{kgf} / \mathrm{mm}^{2}$ \\
& $E_{2}$ (焼鈍部) & 890( & $0) \mathrm{kgf} / \mathrm{mm}^{2}$ \\
& $\sigma_{y}$ (焼鈍部) & $190(60) \mathrm{kgf} / \mathrm{mm}^{2}$ \\
\hline 軸側焼鈍部長さ & $l_{a}$ & 75 & $\mathrm{~mm}$ \\
\hline 軸側移行部長さ & $l_{b}$ & 30 & $\mathrm{~mm}$ \\
\hline
\end{tabular}

\section{表 3 諸元及び要求仕様}

\begin{tabular}{|c|c|c|c|}
\hline \multirow{3}{*}{ ばね諸元 } & $h$ & 0.23 & $\mathrm{~mm}$ \\
\hline & $b$ (板巾) & 7 & $\mathrm{~mm}$ \\
\hline & $l$ & 4000 & $\mathrm{~mm}$ \\
\hline \multirow{2}{*}{ 使用空間 } & $d_{c}$ & $\phi 58$ & $\mathrm{~mm}$ \\
\hline & $d_{s}$ & $\phi 15$ & $\mathrm{~mm}$ \\
\hline \multirow{2}{*}{ 加工条件 } & $d_{1}$ & $\phi 28$ (一定) & $\mathrm{mm}$ \\
\hline & $d_{2}$ & $\phi 10.5$ & $\mathrm{~mm}$ \\
\hline \multirow{3}{*}{ 要求仕様 } & \multicolumn{3}{|c|}{ 数 6.0 のとき) } \\
\hline & \multicolumn{3}{|c|}{$\begin{array}{r}\text { トルク } 14.0 \pm 1.0 \mathrm{kgf} \cdot \mathrm{mm} \\
\text { 数 } 18.0 \text { のとき) }\end{array}$} \\
\hline & \multicolumn{3}{|c|}{ 使用巻数範囲 $6.5 \sim 18.5$ 卷 } \\
\hline
\end{tabular}

4.1 数值解析の手順

数值解析の手順については, ブロック図として図 6 に示す.

実際の数值解析においては，焼鈍部の材料定数分布 を考慮するために, 展開長 $l$ の分割数 $n_{1}$ を比較的大き くとり，また被積分関数が滑らかであるという理由か ら, (12) 式の数值積分は単純な台形公式を用いている. また, 今の場合加工条件としての 1 次巻曲率 $\chi_{1}$ は一定 


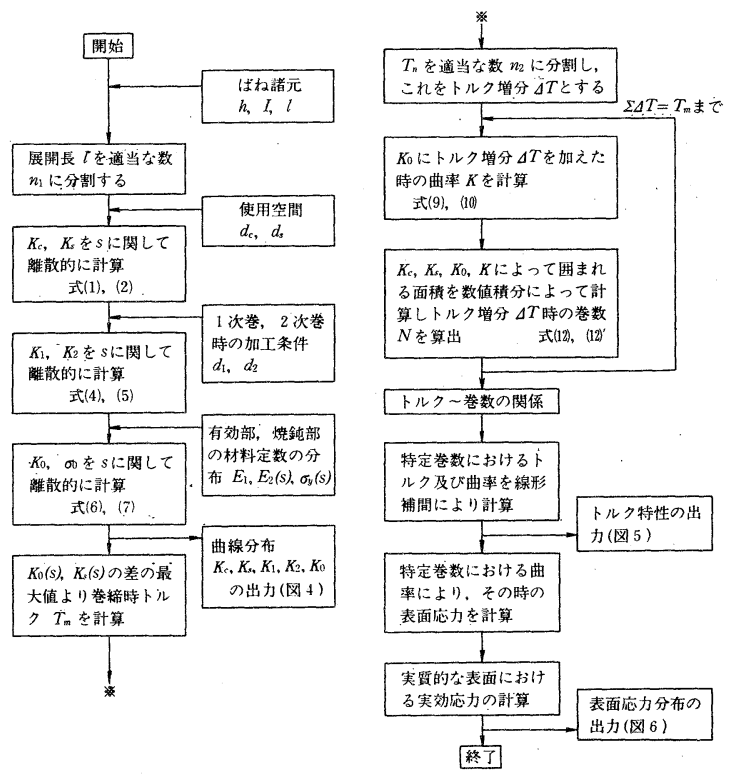

図 6. 数值解析の手順

曲率であるが，(4)式で示される通り，任意な形をとっ ていても解析の手順には何ら変わりはない。したがっ て $S$ 字形ではなく単純うず巻形のばねでも全く同じ取 り扱いである。

4.2 自由状態の形状

(6) 式によって自由状態の曲率分布 $x_{0}$ が得られれば, $s=s_{0}$ での接線角 $\theta$ とその位置の座標 $x, y$ は

$$
\begin{aligned}
\theta=\int_{0}^{s_{0}} \chi_{0} d s, x & =\int_{0}^{s_{0}} \cos \theta d s \\
y & =\int_{0}^{s_{0}} \sin \theta d s
\end{aligned}
$$

で表わされる。つまり $x_{0}$ によって，ばねの自由状態で の形状を知ることができ，これを図 $7 \mathrm{a} ， \mathrm{~b}$ に示す.

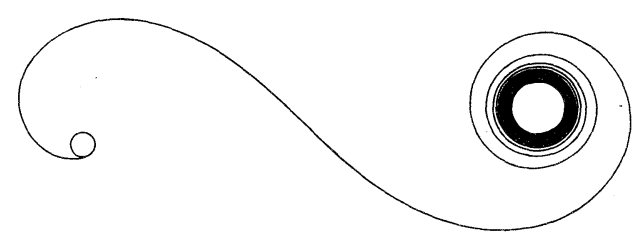

図 7ａ．焼鈍部を考慮した場合の形状

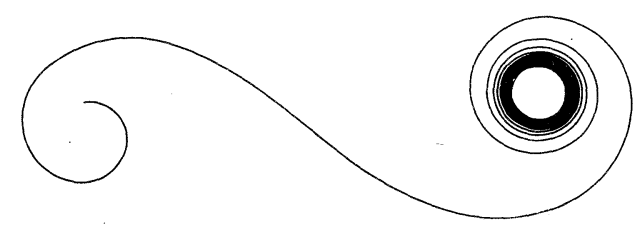

図 7，b、焼鈍部を考慮しない場合の形状
焼鈍部での材料定数の分布を考慮した場合の形状が図

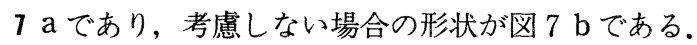

図 $7 \mathrm{a}$ は，実際のばね形状と良く一致しており，この 考慮をすることによって，現実により近い数值解析が 可能であることを示している，なお，ばね有効部と焼 鈍部との間の移行部分については，材料定数の分布を 線形補間している．また，ここでは展開長 $l$ に関する 分割数 $n_{1}$ を非常に大きくとることにより滑らかな形状 を得ており，(14) 式の数值積分は(12) 式の場合と同じ く台形公式を用いている。

\section{3 曲率線図}

図 8 は $x_{1}, x_{2}$ 及び $x_{c} ， x_{s}$ そして $x_{0}$ の曲率分布を計 算したものである.もちろん $x_{0}$ は焼鈍部の材料定数分 布を考慮し，また $x_{1}$ は一定曲率である。ここでは (12) 式で示される積分計算が実用上充分な精度で行なえれ ば良いだけであるので, $l$ に関する分割数 $n_{1}$ は前節に 比べて小さくとっている. また図中 $x_{a}, x_{b}$ は使用され る巻数範囲（この場合には，N=6.5, 18.5)においての (10)式で表わされる曲率分布である。

\section{4 トルク特性}

図 8 の曲率線図において, (9) 式のトルク增分を与之 た場合の曲率変化に対して (12)式の積分計算を順次繰 ク返してゆけば, トルク特性が図９のように得られる。

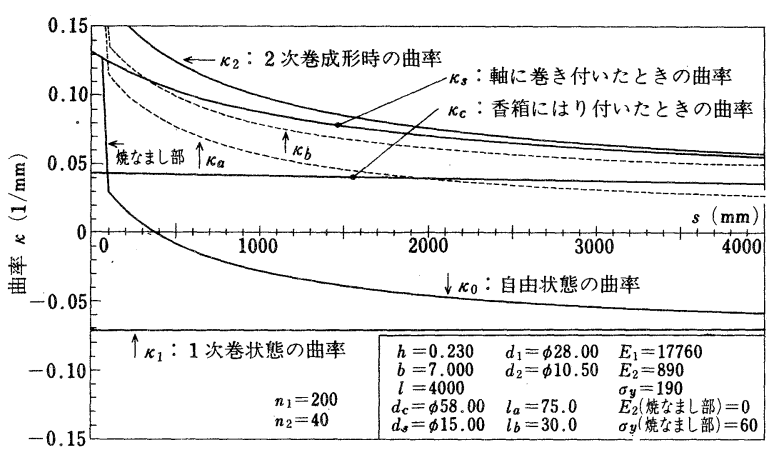

図 8．曲率線図

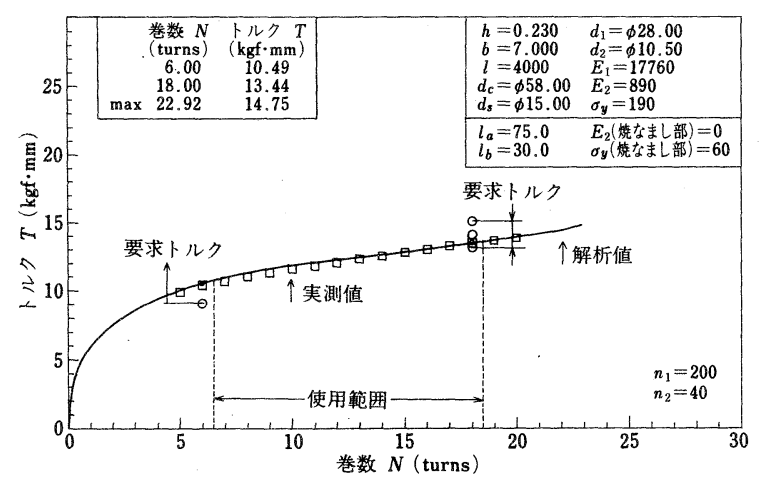

図 9、トルク特性 
トルク増分を得るためのトルク分割数 $n_{2}$ は特性曲線が 滑らかになるように選んでいる。また図中の○印は特 定巻数(この場合 $N=6,18)$ での要求されるトルク仕様 を表わしている. 図中の表にはその巻数でのトルク計 算值を載せており，さらに同表には計算上のこのばね の最大巻数及びトルク終值も記載されている.

口印はこのばねの巻締め時と巻戻し時の実測トルク の平均值を示している.計算値は実測値と非常に良く 一致しており，このことは本報による数值解析の妥当 性, 並びに材料定数の実験的推定方法の妥当性を示し ていると言えよう。

\section{5 表面応力線図}

図 10 に，(7)式で計算される表面での初期残留応力 $\sigma_{0}$, 巻数 0 及び最大での表面応力, 使用巻数 $(N=6.5$, 18.5)での表面応力の分布を示す. 縦軸は応力, 横軸は 曲率線困と同じ軸側から鋼带に沿ってとった長さ $s$ を 表している.さらに図中には，巻数 0 〜最大，及び使 用巻数間のそれぞれの表面応力振幅も表わされている.

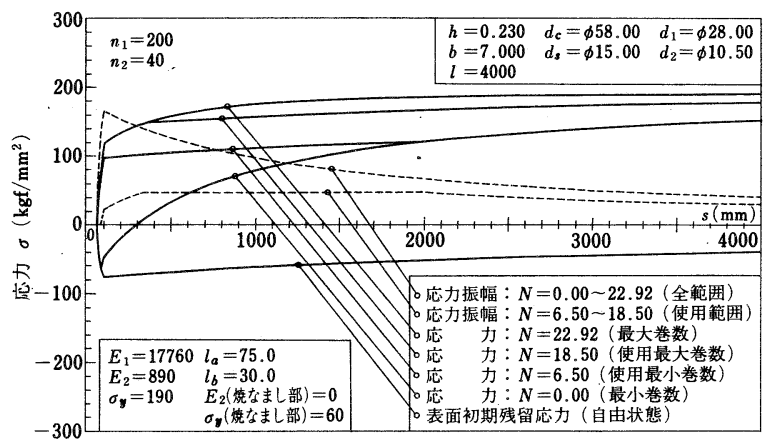

図10.表面応力線図

ここでの表面応力は，いずれも初期残留応力を考慮し た実質的な表面実効応力の分布である.

4.6 加工条件を変化させた場合のトルク特性

4.1 節の数值解析の手順さえ確立すれば, 加工条件な どが変わった場合，主にトルク特性に関してのシミュ レートは容易である.図 $11 \mathrm{a}$ は 2 次巻軸径を変化させ た場合のトルク特性の変動を示し,そして図 $11 \mathrm{~b}$ は 1 次巻径 $d_{1}, 2$ 次巻軸径 $d_{2}$ を共に変えた場合でのトルク 特性の変動を表わしている.

さらに, 図 $11 \mathrm{c}, \mathrm{d}$ は $d_{1}, d_{2}$ をパラメー夕とした場 合の特定巻数 (この場合トルク指定のある巻数 $N=6$, 18）でのトルク変化を立体的に表現したものである.同 四によって，ばね諸元，使用空間，材料定数を同一に し，加工条件を変えた場合でのトルク特性の変化を全 体的に見通すことができる，仮に，特定巻数でのトル ク要求值が求められている場合, ばねの加工条件の決 定をこれらの四をもとに設計段階で行なうことが可能 である。

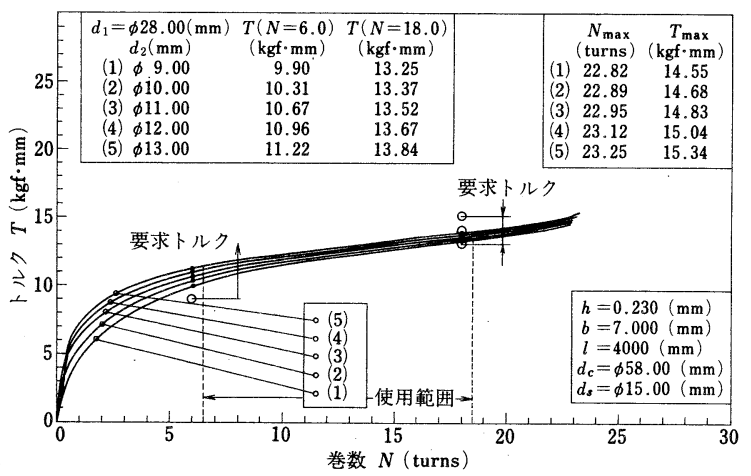

図11、a. 2 次巻軸径を変化させた場合のトルク特性

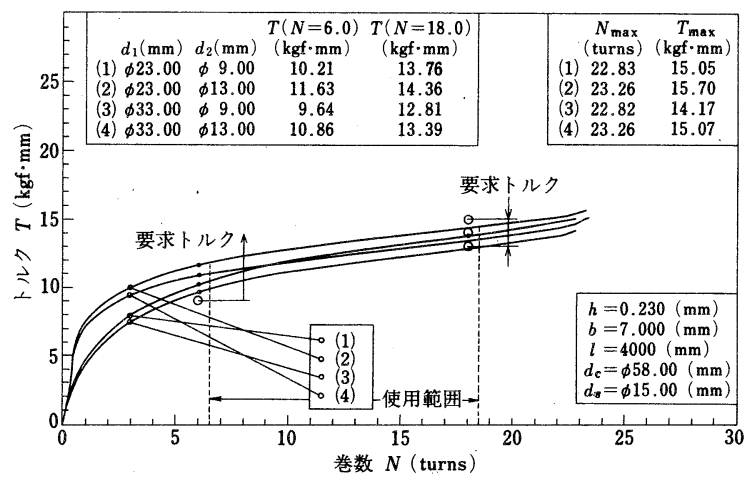

図11. b. 1 次巻径, 2 次巻軸径を変化させた場合のト ルク特性

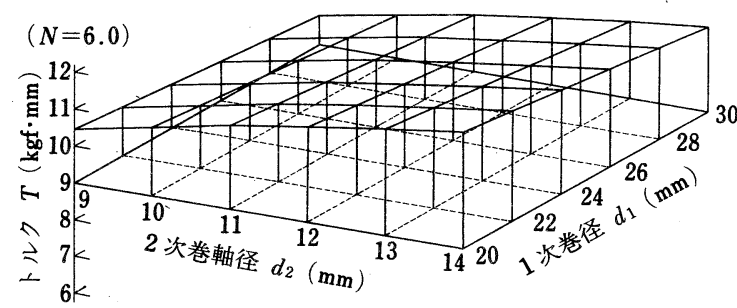

図11. c. 加工条件をパラメータとしたトルク $(N=6.0)$

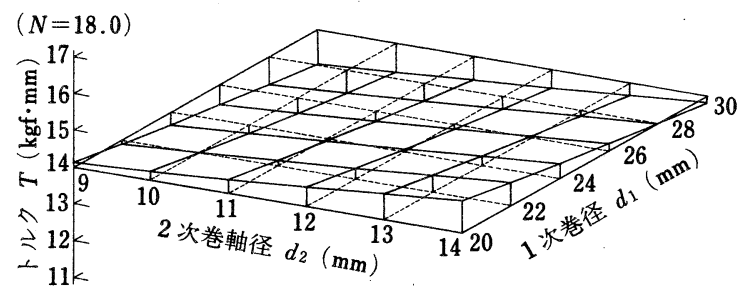

図11. d. 加工条件をパラメータとしたトルク $(N=18.0)$ 


\section{5. あとがき}

うず巻ばねの計算式は, 積分方程式として定式化さ れるために，手計算では実際の解析が困難であった. その点, 本報に示す計算機での数值解法によれば, 処 理は容易である。しかも，位置による材料定数の分布 を考之さ之すれば，焼鈍部の形状もより現実に則した 近似となり，解析も実際のものに近づけることが可能 である。

さらに，成形加工時の初期残留応力を考慮に入れた 実効曲げ応力の分布も算定できるため，折損位置の予 測が可能である。これに，表面応力と寿命との実験的 相関関係を加味さえすれば，設計段階での寿命推定に まで拡張することができる。

また, 解析結果が実測のものとほぼ一致しているこ とから, 解析方法と並びに材料定数の実験的推定方法 とが妥当なものであると言える。

\section{6. 補 遗}

2 章では $x_{c}, x_{s}, \chi_{1}, x_{2}, x_{0}$, それに $\sigma_{0}$ の具体的内 容は省略したが，ここに示しておく．記号は本文中の ものと同一であり，また，特に $\varkappa_{0}$ の導出には文献 1 )を 参照されたい.

$$
\begin{aligned}
x_{c} & =x_{c}\left(s ; d_{c}, h, l\right) \\
& =\left[\left\{\left(d_{c}-h\right) / 2\right\}^{2}-(h / \pi)(l-s)\right]^{-1 / 2} \\
x_{s} & =x_{s}\left(s ; d_{s}, h\right) \\
& =\left[\left\{\left(d_{s}+h\right) / 2\right\}^{2}+(h / \pi) s\right]^{-1 / 2}
\end{aligned}
$$

$$
\begin{aligned}
& \varkappa_{1}=\chi_{1}(s) \\
& =-1 /\left(d_{1} / 2\right)=-2 / d_{1} \\
& \chi_{2}=\chi_{2}\left(s ; d_{2}, h\right) \\
& =\left[\left\{\left(d_{2}+h\right) / 2\right\}^{2}+(h / \pi) s\right]^{-1 / 2} \\
& \chi_{0}=\chi_{0}\left(s ; \chi_{1}, \chi_{2}, h, E_{1}, E_{2}, \sigma_{y}\right) \\
& =\chi_{1}+\left(1-E_{2} / E_{1}\right)\left(\chi_{2}-\chi_{1}\right) \\
& \times\left[1-3\left[\sigma_{y} /\left\{E_{1} h\left(\chi_{2}-\chi_{1}\right)\right\}\right]+4\left[\sigma_{y} /\left\{E _ { 1 } h \left(\chi_{2}\right.\right.\right.\right. \\
& \left.\left.\left.\left.-\chi_{1}\right)\right\}\right]^{3}\right] \\
& \sigma_{0}=\sigma_{0}\left(s ; \varkappa_{1}, \varkappa_{2}, h, E_{1}, E_{2}, \sigma_{y}\right) \\
& =(1 / 2)\left(1-E_{2} / E_{1}\right) \sigma_{y} \\
& \times\left[4\left[\sigma_{y} /\left\{E_{1} h\left(\varkappa_{2}-\varkappa_{1}\right)\right\}\right]^{2}-1\right]
\end{aligned}
$$

ただし, 本報の場合 $x_{1}=$ 一定としたが, $x_{1}$ は一般に は任意である。

\section{謝 辞}

材料定数測定実験に用いたうず巻ばね, 鋼帯試験片, 及びトルク特性実測值などを御提供いただいた速水発 条株式会社に梁く感謝いたします。

1）吉本，花房：機械学会論文集，18 巻 71 号，p.1720 (昭 27).

$2)$ Swift, W. A. C. : Proc Instr Mech Engrs., Vol. 188 50, p.615-625(1974).

3) Queener, C. A., Wood, G. E. : Journal of Engineering for Industry, May 1971, TRANS. ASME, p.667-675. 